\title{
The Effects of Leadership, Competence, and Organizational Culture on Employee Performance Mediated By Employee Satisfaction
}

\author{
Triono Nugroho ${ }^{1}$, Anita Erari ${ }^{2}$, Sandra Sukmaning Adji ${ }^{3}$ \\ 1,2,3Faculty of Economics, Universitas Terbuka, Indonesia \\ Email: trionug5@gmail.com, aerari@yahoo.co.id,sandra@ecampus.ut.ac.id
}

\begin{abstract}
:
Improving employee performance is an important and mandatory thing to be realized, especially in local government organizations. This study aims to determine and analyze the influence of leadership, competence and organizational culture on employee performance mediated by employee job satisfaction. This research was conducted on the employees of the Department of Investment and One Stop Services (DPMPTSP) of Yapen Islands Regency with a population of 32 employees, where all employees were used as samples. The independent variables in this study are leadership, competence and organizational culture, while the dependent variable is employee performance mediated by job satisfaction. The research data was obtained by distributing questionnaires and then measuring the variables using a Likert scale. Furthermore, the data were analyzed using a Structural Equation Model (SEM) approach based on Partial Least Square (PLS), namely Smart-PLS version 3. The results showed that: 1) leadership had no significant effect on employee performance, but had a significant effect on job satisfaction; 2) competence has a significant effect on employee performance, but is not significant in influencing job satisfaction; 3) organizational culture has a significant effect on employee performance and job satisfaction; 4) job satisfaction has a significant effect on employee performance; 5) job satisfaction can mediate the relationship of leadership to employee performance, but cannot mediate the relationship of competence and organizational culture to employee performance.
\end{abstract}

Keywords: leadership; competence; organizational culture; job satisfaction; employee performance

\section{Introduction}

The Office of Investment and One-Stop Integrated Services (DPMPTSP), which exists in many Indonesian regencies, is a local organization with a specific task to manage and provide assistance related to local investment (Kojo et al., 2019). The vision of DPMPTSP is to provide excellent service and business convenience at the local level. To achieve this vision, the DPMPTSP is required to immediately carry out licensing/non-licensing services online using the Online Single Submission (OSS) and Si Cantik Cloud applications. Using online applications for licensing services allows the business and investment in the local area to increase due to the easiness and process transparency. In addition, it will be easier for business practitioners and investors to obtain information related to licensing services, faster to register for licensing online, and less consuming time to issue the permits (Warokka, 2010). 
Related to the observed local organization (the Yapen Islands Regency' DPMPTSP), it could not implement an integrated licensing service system using the OSS and Si Cantik Cloud applications. One of the obstacles is the inadequate office internet facilities. Therefore, the non-operation of the integrated licensing service system indicates that the observed local organization is still not optimal.

Several previous researchers have examined the factors that affect the performance of DPMPTSP employees in various regions in Indonesia. For instance, organizational culture (Yulianto \& Ali, 2017), work motivation (Subriah et al., 2020), and leadership (Rahmat et al., 2020). In addition, the are other factors as well, for instance, work environment (Khaeriah et al., 2020), competence (Khaeriah et al., 2020), job satisfaction (Fitri et al., 2020), training (Fitri et al., 2020; Khaeriah et al., 2020), work discipline (Subriah et al., 2020), and compensation (Wiadnyana et al., 2021). From these many factors, the researcher chose several factors included in the initial survey to find out which factors had the most influence on the performance of employees at the observed local organization. Thus, the respondents could choose more than one factor that had the most influence on employee performance.

In the context of the observed local organization, the results of the initial survey analysis showed that more than $50 \%$ of employees chosen four influencing factors of employee performance. The four factors are organizational culture $(90.6 \%)$, competence $(81.3 \%)$, leadership (81.3\%), and job satisfaction (65.6\%). Furthermore, these four factors will be the studied variables in this study to analyze their influence on employee performance.

Leadership is a critical factor in public sector organizations because managing the employees will determine the organization's success in the future (Kaiser et al., 2008). Previous studies found differences in leadership impacts on employee performance in various regions in similar observed organizations. For instance, Subriah et al. (2020) examined the performance of employees at Majene Regency's DPMPTSP. They found that performance appraisal and feedback were the indicators of leadership that had the most considerable influence on employee performance. Furthermore, Rahmat et al. (2020) found that leaders who have good communication with employees and involve employees in decision-making have the highest average score on employee performance at Makassar's DPMPTSP.

Furthermore, to realize the success of public services in the current era of digitalization, talented human resources are needed (Mazurchenko \& Maršíková, 2019). Many employees had not undergone education, and training led to the low level of serving the community. Khaeriah et al. (2020) and Fitri et al. (2020) found that the competency factor is an essential factor that significantly affects the performance of Barru Regency's DPMPTSP employees.

\section{Review of Literatures}

\subsection{Employee Performance}

According to Bernardin and Russell (2013), performance results from a particular job function and within a certain period. The work results are the results of the abilities, skills, and desires achieved. Various factors can affect employee performance, and these factors are essential to improve a particular series of activities to achieve predetermined organizational goals (Spencer \& Spencer, 1993). 


\subsection{Leadership}

Previous empirical findings show that leadership factors significantly influence employee performance. Those findings confirmed the influence of leadership on employee performance in the public sector. Pudyaningsih et al., (2020), also found a leadership that provides support, growth opportunities, and pays attention to employee needs strongly influences employee performance in the public sector. Talented leaders will be able to identify the basic needs of employees and have a commitment to meet these employee needs effectively (Braun et al., 2013). When the needs and desires of employees are met, it will affect improving performance, and employees are satisfied with their work (Okaychukwu, 2017). Shahab and Nisa (2014) and Pudyaningsih et al. (2020) also found that the better the leadership role, the higher the job satisfaction of employees in the public sector. Based on the theory and previous empirical findings, the proposed hypotheses are as follow:

H1: Leadership affects the employee performance

H2: Leadership affects the job satisfaction

\subsection{Competence}

Salman et al. (2020) found that the competencies possessed by employees in the form of team competencies, social competencies, communication competencies had a positive and significant influence on the organizational performance of public and private sector banks. The better the competencies possessed by employees, the better the performance of the employees produced (Jusmin et al., 2016). More specifically, Sulantara et al. (2020) can prove that employee competence significantly affects employee performance in Bali Province's DPMPTSP. Jusmin et al. (2016) Finding high competence will encourage employees to feel more satisfied with their work. Based on prior empirical findings, the proposed hypotheses are as follow:

H3: Competence affects the employees' performance

H4: Competence affects the job satisfaction

\subsection{Organizational Culture}

Organizational culture is a dynamic force in a rotating, engaging, and interactive organization that employees, management, attitudes, and behavior shape the culture simultaneously (Schein, 2004). Organizations with a strong culture will create outstanding employee personalities and support continuous employee improvement (Kawiana et al., 2018). Other than that, Makawi et al. (2020), and Maryati et al. (2019) found a significant influence of organizational culture on employee performance. Researchers have proven that organizational culture significantly influences job satisfaction (Al-Sada et al., 2017). Therefore, based on the prior empirical findings, the proposed research hypotheses are as follow:

H5: Organizational culture affects the employees' performance

H6: Organizational culture affects the job satisfaction

\subsection{Job Satisfaction}

Galup et al. (2008) found that high levels of employee satisfaction usually contribute to the success of an organization, while poor job satisfaction can undermine that success. When the employee is satisfied with the salary and other things he receives from the company, satisfaction becomes the impetus to work better and increases performance (Fitri et al., 2020). Previous researchers have confirmed the significant effect of job satisfaction on employee performance (Jusmin et al., 2016; Kawiana et al., 2018). More specifically, Shahab and Nisa (2014) found that job satisfaction significantly affects employee performance in the public sector. Based on the theory and empirical findings, the proposed seventh hypothesis is as follow:

H7: Job satisfaction affects the employees' performance 
Previous empirical findings indicate that employee job satisfaction can mediate the effects of various human resource management practices on employee performance (Fried et al., 2008). For example, leaders who pay attention to and meet the needs of subordinates will be able to improve job satisfaction so that subordinates will be inspired to provide better performance. Thus, job satisfaction factors can mediate the relationship of leadership to employee performance (Makawi et al., 2020; Pudyaningsih et al., 2020). Satisfied employees are highly motivated to provide good service to customers (Makawi et al., 2020). In addition, Jusmin et al. (2016) found that job satisfaction has a mediating effect in the relationship between competence and employee performance. Besides being able to mediate the effects of leadership and competence on employee performance, other empirical findings also prove that job satisfaction can mediate the influence of organizational culture on employee performance (Makawi et al., 2020). Based on the previous empirical findings, the proposed eighth, the ninth, and the tenth hypothesis are as follow, respectively:

H8: The effect of leadership on employee performance mediated by job satisfaction

H9: The effect of competence on employee performance mediated by job satisfaction

H10: The effect of organizational culture on employee performance mediated by job satisfaction

The proposed ten hypotheses in this study are then summarized in the following research model (Figure 1).

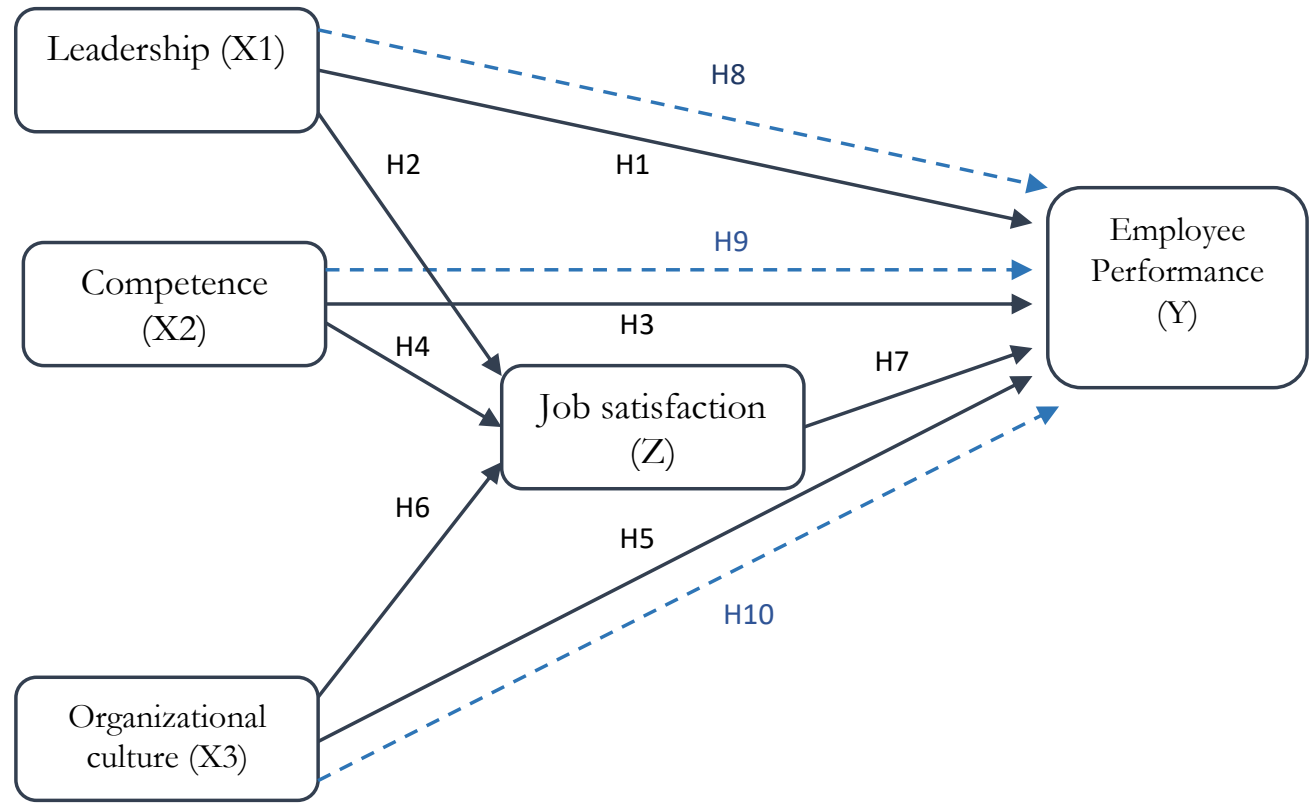

$\longrightarrow$ Direct Influence

$---\rightarrow$ Indirect Influence

Figure 1. Research Model

\section{Research Methods}

This study uses quantitative research methods that use specific techniques to test theories and examine the relationship between variables in one study. The research data was obtained directly from filling out the compiled questionnaires by using a 5-point Likert scale. The respondents in this study were all employees of Yapen Islands Regency's DPMPTSP, totaling 32 people. The saturated sampling technique was used for sampling because the total population was small. 
The research hypothesis was tested using a Structural Equation Model (SEM) approach based on Partial Least Square (PLS). PLS is an alternative Structural Equation Modeling method in dealing with very complex variables, abnormal data distribution, and small data sample size (sample <100). Chin (2010) recommends that for reporting the results of the PLS analysis, it is better to use a two-step approach or a two-step approach, namely the evaluation of the measurement or the outer model and the evaluation of the model or the inner model (Hair et. al., 2016).

\section{Results and Discussion}

The characteristics of the respondents are first analyzed to determine whether the pattern of answers of each respondent will have the same or not. In this study, the characteristics of the respondents were gender, age, education level, and level of structural position (table 1).

Table 1. Characteristics of Research Respondents

\begin{tabular}{cccc}
\hline Category & Alternative Answer & $\begin{array}{c}\text { Number of } \\
\text { Respondents }\end{array}$ & Percent (\%) \\
\hline \multirow{2}{*}{ Gender } & Male & 15 & 46.9 \\
& Female & 17 & 53.1 \\
\hline \multirow{5}{*}{ Age } & 26-30 Years & 1 & 3.1 \\
& $31-35$ Years & 5 & 15.6 \\
& 36- 40 Years & 6 & 18.8 \\
& $41-45$ Years & 11 & 34.4 \\
& $46-50$ Years & 6 & 18.8 \\
& $51-55$ Years & 2 & 6.2 \\
Level of education & 56-58 Years & 1 & 3.1 \\
\hline \multirow{5}{*}{ Echelon } & High School & 4 & 12.5 \\
& 3-year Diploma & 2 & 6.2 \\
& Bachelor Degree & 22 & 68.8 \\
& Master Degree & 4 & 12.5 \\
\hline & II.a & 1 & 3.1 \\
& III.a & 1 & 3.1 \\
& III.b & 4 & 12.5 \\
& IV.a & 15 & 46.9 \\
& Functional Staff & 11 & 34.4 \\
\hline
\end{tabular}

Based on the results of the analysis of the characteristics of the respondents, it can be seen that the observed local organization is dominated by female employees $(53 \%)$, in the age range of 41-45 years (34.4\%), undergraduate graduates (S1) (68 .8\%), and with echelon IV.a (46.9\%). Employees at the observed local organization are dominated by productive age employees and have a good level of education. Therefore, it is expected to produce maximum performance.

Furthermore, the respondents' answers are used to determine the perceptions or opinions given by the respondents to each variable. Therefore, the analysis is undertaken to calculate the average value of respondents' responses to each question. An interval scale, which is calculated from the highest score minus the lowest score divided by five, to categorize respondents' answers, is 0.80 (Sugiyono, 2013). Based on Sugiyono (2013), the categorization system is as follows: $1.00-$ 1.80 (very low); $1.81-2.60$ (low); $2.61-3.40$ (moderate); $3.41-4.20$ (high); and $4.21-5.00$ (very high). Table 2 presents the distribution of respondents' opinions. 
Table 2. Description of Respondents' Answers

\begin{tabular}{|c|c|c|c|c|c|}
\hline Y1 & Employee Performance (Y) & Total & $\mathbf{N}$ & mean & Category \\
\hline Y1.1 & $\begin{array}{l}\text { I can complete work according to } \\
\text { standards. }\end{array}$ & 128 & 32 & 4.00 & High \\
\hline Y1.2 & $\begin{array}{l}\text { My work is completed on time } \\
\text { according to standards. }\end{array}$ & 119 & 32 & 3.72 & High \\
\hline Y1.3 & $\begin{array}{l}\text { I commit to carry out and complete } \\
\text { the work. }\end{array}$ & 131 & 32 & 4.09 & High \\
\hline Y1.4 & $\begin{array}{l}\text { I am used to maintaining cooperative } \\
\text { relationships with colleagues in } \\
\text { completing organizational tasks. }\end{array}$ & 137 & 32 & 4.28 & High \\
\hline Y1.5 & $\begin{array}{l}\text { I always take the initiative to complete } \\
\text { assignments and provide feedback on work }\end{array}$ & 132 & 32 & 4.13 & High \\
\hline \multicolumn{4}{|c|}{ Average Employee Performance Variable (Y) } & 4.04 & High \\
\hline $\mathbf{X} 1$ & Leadership (X1) & Total & $\mathbf{N}$ & mean & Category \\
\hline $\mathrm{X} 1.1$ & $\begin{array}{l}\text { Leaders are fair and objective towards } \\
\text { all employees }\end{array}$ & 133 & 32 & 4.16 & High \\
\hline $\mathrm{X} 1.2$ & $\begin{array}{l}\text { Leaders always provide support, } \\
\text { insight, awareness of the mission to } \\
\text { work success. }\end{array}$ & 140 & 32 & 4.38 & Very high \\
\hline $\mathrm{X} 1.3$ & $\begin{array}{l}\text { Leaders always convey goals that can } \\
\text { be achieved from the input in work }\end{array}$ & 132 & 32 & 4.13 & High \\
\hline $\mathrm{X} 1.4$ & Leaders consider ability on the job & 132 & 32 & 4.13 & High \\
\hline $\mathrm{X} 1.5$ & $\begin{array}{l}\text { Leaders can decide and solve } \\
\text { problems at work }\end{array}$ & 133 & 32 & 4.16 & High \\
\hline X1.6 & $\begin{array}{l}\text { Leaders in their behavior, actions, and } \\
\text { words should be an excellent example } \\
\text { for the organization. }\end{array}$ & 135 & 32 & 4.22 & Very high \\
\hline $\mathrm{X} 1.7$ & $\begin{array}{l}\text { Leaders can make positive changes to } \\
\text { subordinates at work }\end{array}$ & 133 & 32 & 4.16 & High \\
\hline $\mathrm{X} 1.8$ & $\begin{array}{l}\text { Leaders give pride to the work of } \\
\text { subordinates. }\end{array}$ & 137 & 32 & 4.28 & Very high \\
\hline \multicolumn{4}{|c|}{ Leadership Variable Mean (X1) } & 4.20 & High \\
\hline $\mathrm{X} 2$ & Competence (X2) & Total & $\mathbf{N}$ & mean & Category \\
\hline $\mathrm{X} 2.1$ & $\begin{array}{l}\text { I have a strong sense of purpose in } \\
\text { doing work }\end{array}$ & 132 & 32 & 4.13 & High \\
\hline $\mathrm{X} 2.2$ & I am ready to work hard in doing the job & 132 & 32 & 4.13 & High \\
\hline $\mathrm{X} 2.3$ & I am responsible for every job & 132 & 32 & 4.13 & High \\
\hline $\mathrm{X} 2.4$ & $\begin{array}{l}\text { With the knowledge I have, I can } \\
\text { complete the given task }\end{array}$ & 136 & 32 & 4.25 & Very high \\
\hline $\mathrm{X} 2.5$ & $\begin{array}{l}\text { I can use work equipment such as } \\
\text { computers, and others related to } \\
\text { internet access. }\end{array}$ & 123 & 32 & 3.84 & High \\
\hline \multicolumn{4}{|c|}{ Average Competency Variable (X2) } & 4.09 & High \\
\hline $\mathrm{X} 3$ & Organizational Culture (X3) & Total & $\mathbf{N}$ & mean & Category \\
\hline $\mathrm{X} 3.1$ & $\begin{array}{l}\text { I have broad opportunities and am } \\
\text { proactive in improving the work } \\
\text { management system, creating new } \\
\text { ideas, and working in completing } \\
\text { work. }\end{array}$ & 127 & 32 & 3.97 & High \\
\hline
\end{tabular}


X3.2 If a problem arises at work, always 138 solve it together

X3.3

Assignments are given according to my abilities and expertise.

X3.4 I can utilize all lines of communication for task execution and completion Leaders provide support in the form

X3.5 of communication when obstacles are found in completing work

X3.6

I have a strong desire to achieve organizational goals

When faced with a task problem, I was given the freedom to present it to find the best solution with the leaders and co-workers.

In the organization, a democratic communication pattern between

X3.8 leaders and subordinates makes it easier for employees to convey personal ideas and opinions.

\begin{tabular}{|c|c|c|c|c|c|}
\hline \multicolumn{4}{|c|}{ Average Organizational Culture Variable (X3) } & \multirow{2}{*}{$\begin{array}{l}4.27 \\
\text { mean }\end{array}$} & \multirow{2}{*}{$\begin{array}{l}\text { Very high } \\
\text { Category }\end{array}$} \\
\hline $\mathrm{Z}$ & Job Satisfaction (Z) & Total & $\mathbf{N}$ & & \\
\hline Z.1 & I am satisfied with my current salary & 83 & 32 & 2.59 & Low \\
\hline & I am satisfied with my current job & 124 & 32 & 3.88 & \\
\hline Z.2 & $\begin{array}{l}\text { because I get the opportunity to learn, } \\
\text { and the responsibilities of the } \\
\text { leadership }\end{array}$ & & & & High \\
\hline Z.3 & $\begin{array}{l}\text { I am satisfied with the opportunity to } \\
\text { grow (Promotion) at DPMPTSP }\end{array}$ & 119 & 32 & 3.72 & High \\
\hline Z.4 & $\begin{array}{l}\text { Internal supervision in DPMPTSP is } \\
\text { carried out properly without any } \\
\text { discrimination (like or dislike factor) }\end{array}$ & 105 & 32 & 3.28 & High \\
\hline Z.5 & $\begin{array}{l}\text { I feel comfortable and satisfied to have } \\
\text { solid colleagues in DPMPTSP }\end{array}$ & 121 & 32 & 3.78 & High \\
\hline Z.6 & $\begin{array}{l}\text { The current workplace is relatively safe } \\
\text { and comfortable at work }\end{array}$ & 136 & 32 & 4.25 & Very high \\
\hline & Mean Job Satisfaction Variable & & & 3.58 & High \\
\hline
\end{tabular}

From Table 2, it can be seen that the organizational culture variable has a very high overall average value of 4.27. In contrast, the variables of leadership, competence, and job satisfaction have a high average value of $4.20,4.09$, and 3.58, respectively. The high average indicates that the average respondent considers that leadership, competence, organizational culture, and job satisfaction strongly influence employee performance.

\subsection{Measurement Model Evaluation}

Evaluation of the measurement model provides an evaluation of the accuracy (construct reliability) and validity of the items (convergent and discriminant). Convergent validity test helps to understand the correlation between variables and research instruments by estimating outer loading and AVE (average of extracted variance). According to Chin et al.(2008), the proper outer loading has values above 0.6 and AVE above 0.5. Table 3 shows that the outer loading and AVE values meet the criteria. Four items were deleted because they 
had an outer loading value of less than 0.6, namely X2.1, Z.1, Z.4, and Y.4. Based on the estimation results, the variables and research instruments were declared valid.

The next test is discriminant validity using cross-loading, as presented in Table 4 . The highest value for each indicator is higher than the loading value for other variables (e.g. X1.1 has the highest loading on the X1 variable, and the loading value is smaller for other variables). The composite reliability (CR) value with the eligibility criteria above 0.7 proves whether the instrument produces a consistent score when used to measure variables (Hair et al., 2016). The test results in table 3 show that all variables have a CR value $>0.7$. So that all variables meet the reliability requirements.

Table 3. Factor Loading and Reliability Coefficients

\begin{tabular}{|c|c|c|c|}
\hline Items & Loading & AVE & CR \\
\hline Leadership (X1) & & 0.792 & 0.968 \\
\hline $\mathrm{X} 1.1$ & 0.929 & & \\
\hline $\mathrm{X} 1.2$ & 0.897 & & \\
\hline $\mathrm{X} 1.3$ & 0.929 & & \\
\hline $\mathrm{X} 1.4$ & 0.848 & & \\
\hline X1.5 & 0.904 & & \\
\hline $\mathrm{X} 1.6$ & 0.856 & & \\
\hline $\mathrm{X} 1.7$ & 0.903 & & \\
\hline $\mathrm{X} 1.8$ & 0.848 & & \\
\hline Competence (X2) & & 0.742 & 0.920 \\
\hline $\mathrm{X} 2.2$ & 0.864 & & \\
\hline $\mathrm{X} 2.3$ & 0.918 & & \\
\hline $\mathrm{X} 2.4$ & 0.886 & & \\
\hline X2.5 & 0.771 & & \\
\hline $\mathrm{X} 2.2$ & 0.864 & & \\
\hline Organizational Culture (X3) & & 0.642 & 0.935 \\
\hline $\mathrm{X} 3.1$ & 0.739 & & \\
\hline $\mathrm{X} 3.2$ & 0.861 & & \\
\hline $\mathrm{X} 3.3$ & 0.730 & & \\
\hline $\mathrm{X} 3.4$ & 0.764 & & \\
\hline $\mathrm{X} 3.5$ & 0.847 & & \\
\hline X3.6 & 0.811 & & \\
\hline $\mathrm{X} 3.7$ & 0.895 & & \\
\hline $\mathrm{X} 3.8$ & 0.747 & & \\
\hline Job Satisfaction (Z) & & 0.772 & 0.931 \\
\hline Z.2 & 0.881 & & \\
\hline Z.3 & 0.911 & & \\
\hline Z.5 & 0.898 & & \\
\hline Z.6 & 0.822 & & \\
\hline Employee Performance (Y) & & 0.762 & 0.927 \\
\hline Y.1 & 0.898 & & \\
\hline Y.2 & 0.843 & & \\
\hline Y.3 & 0.894 & & \\
\hline Y.5 & 0.855 & & \\
\hline
\end{tabular}


Table 4. Cross Loading

\begin{tabular}{cccccc}
\hline & \multicolumn{5}{c}{ Variable } \\
Items & $\mathbf{X 1}$ & $\mathbf{X 2}$ & $\mathbf{X 3}$ & $\mathbf{Z}$ & $\mathbf{Y}$ \\
\hline $\mathrm{X} 1.1$ & $\mathbf{0 . 9 2 9}$ & 0.417 & 0.692 & 0.604 & 0.644 \\
$\mathrm{X} 1.2$ & $\mathbf{0 . 8 9 7}$ & 0.376 & 0.576 & 0.638 & 0.556 \\
$\mathrm{X} 1.3$ & $\mathbf{0 . 9 2 9}$ & 0.390 & 0.582 & 0.623 & 0.644 \\
$\mathrm{X} 1.4$ & $\mathbf{0 . 8 4 8}$ & 0.271 & 0.477 & 0.521 & 0.607 \\
$\mathrm{X} 1.5$ & $\mathbf{0 . 9 0 4}$ & 0.418 & 0.711 & 0.738 & 0.745 \\
$\mathrm{X} 1.6$ & $\mathbf{0 . 8 5 6}$ & 0.388 & 0.650 & 0.667 & 0.708 \\
X1.7 & $\mathbf{0 . 9 0 3}$ & 0.580 & 0.795 & 0.707 & 0.678 \\
X1.8 & $\mathbf{0 . 8 4 8}$ & 0.408 & 0.697 & 0.697 & 0.706 \\
X2.2 & 0.432 & $\mathbf{0 . 8 6 4}$ & 0.447 & 0.529 & 0.288 \\
X2.3 & 0.445 & $\mathbf{0 . 9 1 8}$ & 0.590 & 0.672 & 0.531 \\
X2.4 & 0.429 & $\mathbf{0 . 8 8 6}$ & 0.416 & 0.576 & 0.474 \\
X2.5 & 0.250 & $\mathbf{0 . 7 7 1}$ & 0.378 & 0.422 & 0.280 \\
X3.1 & 0.462 & 0.326 & $\mathbf{0 . 7 3 9}$ & 0.560 & 0.604 \\
X3.2 & 0.657 & 0.434 & $\mathbf{0 . 8 6 1}$ & 0.646 & 0.684 \\
X3.3 & 0.661 & 0.498 & $\mathbf{0 . 7 3 0}$ & 0.574 & 0.706 \\
X3.4 & 0.617 & 0.310 & $\mathbf{0 . 7 6 4}$ & 0.545 & 0.478 \\
X3.5 & 0.589 & 0.362 & $\mathbf{0 . 8 4 7}$ & 0.606 & 0.491 \\
X3.6 & 0.526 & 0.595 & $\mathbf{0 . 8 1 1}$ & 0.675 & 0.562 \\
X3.7 & 0.625 & 0.488 & $\mathbf{0 . 8 9 5}$ & 0.785 & 0.611 \\
X3.8 & 0.566 & 0.411 & $\mathbf{0 . 7 4 7}$ & 0.678 & 0.492 \\
Y.1 & 0.747 & 0.430 & 0.724 & $\mathbf{0 . 8 9 8}$ & 0.790 \\
Y.2 & 0.655 & 0.670 & 0.707 & $\mathbf{0 . 8 4 3}$ & 0.728 \\
Y.3 & 0.563 & 0.686 & 0.658 & $\mathbf{0 . 8 9 4}$ & 0.659 \\
Y.5 & 0.596 & 0.485 & 0.687 & $\mathbf{0 . 8 5 5}$ & 0.689 \\
Z.2 & 0.715 & 0.548 & 0.689 & 0.812 & $\mathbf{0 . 8 8 1}$ \\
Z.3 & 0.589 & 0.379 & 0.553 & 0.635 & $\mathbf{0 . 9 1 1}$ \\
Z.5 & 0.745 & 0.390 & 0.691 & 0.734 & $\mathbf{0 . 8 9 8}$ \\
Z.6 & 0.552 & 0.334 & 0.604 & 0.686 & $\mathbf{0 . 8 2 2}$ \\
\hline & & & & &
\end{tabular}

\subsection{Structural Model Evaluation}

The evaluation of the structural model was analyzed with the R-Square value, which is a measurement of the proportion of variation in the value of the affected variable (endogenous), which the exogenous variable can explain. According to Chin et al.(2008), a) if $\mathrm{R}^{2}=0.67$ then the model is substantial (strong); $\mathrm{b}$ ) If $\mathrm{R}^{2}=0.33$ then the model is moderate (medium); and c) If $\mathrm{R}^{2}=0.19$ then the model is weak (bad). The R-Square of the first line model is 0.633 . This finding means that the ability of leadership variables, competence variables, and organizational culture in explaining job satisfaction is $63.3 \%$. It can be concluded that the first model is moderate (medium). Next for the R-Square second line model is 0.809 . It can be interpreted that the constructed variable of employee performance that can be explained by the leadership variable, competence variable, organizational culture, and job satisfaction is $80.9 \%$. In contrast, other variables outside the research explain the rest. From these results, it can be concluded that the second model is substantial (strong). 
Table 5. R-Square Value

\begin{tabular}{lcc}
\hline & R Square & $\begin{array}{c}\text { R Square } \\
\text { Adjusted }\end{array}$ \\
\hline Job Satisfaction $(\mathrm{Z})$ & 0.633 & 0.594 \\
Employee Performance $(\mathrm{Y})$ & 0.809 & 0.780 \\
\hline
\end{tabular}

Figure 2 shows the results of testing the ten hypotheses. Based on the findings of the first hypothesis, it is known that leadership has no significant effect on employee performance. This finding is indicated by the path coefficient value of 0.094 with a p-value of $0.600>0.05$, which means it is not significant. This finding rejects the first hypothesis and cannot support previous research (Pudyaningsih et al., 2020).

The leadership in the observed local organization does not always convey goals to employees based on employee input at work. It does not consider the employee's abilities when assigning tasks or work to employees. This result is in line with Shahab and Nisa (2014), who found that leadership had no significant effect on employee performance in the public sector. Empirical findings also prove that listening to employees' opinions has a positive relationship with work outcomes such as leadership effectiveness (Johnson \& Bechler, 1998), and employee commitment (Lobdell et al., 1993).

Testing the second hypothesis shows that leadership has a significant effect on job satisfaction, as seen from the path coefficient value of 0.453 , and is signed with a $\mathrm{p}$-value of $0.001<0.05$. These results support previous research, which also found a significant influence of leadership on job satisfaction (Pudyaningsih et al., 2020; Shahab \& Nisa, 2014). The leadership at the observed local organization provides insightful support to employees and gives pride or appreciation to employees. Thus employees feel cared for and appreciated by the leadership so that employees feel satisfied in their work.

Furthermore, the test results show that competence significantly affects employee performance and supports the third hypothesis. The path coefficient value is 0.254 , and the $\mathrm{p}$ value is $0.045<0.05$, so that the effect is positive and significant. This finding supports previous research conducted by Jusmin et al. (2016), and Sulantara et al. (2020). An increase in employee competence will elevate employee performance. The competencies possessed by employees at the observed local make it easier for employees to carry out their work to improve performance. 


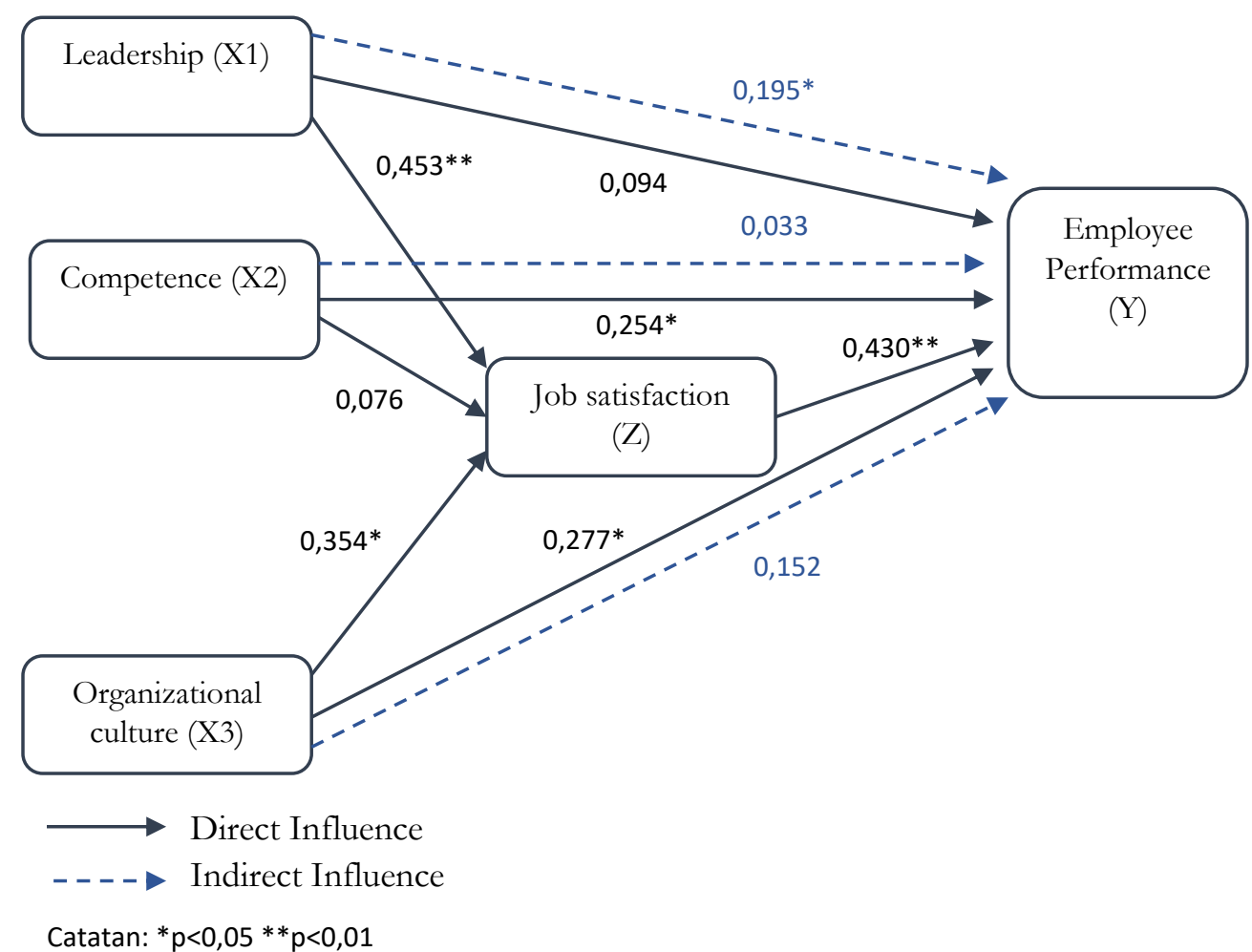

Figure 2. Hypothesis Testing Results

The results of testing the fourth hypothesis prove that competence has no significant effect on employee performance. This result is shown from the path coefficient value of 0.076 and the p-value of $0.547>0.05$, meaning that it has no significant effect. This finding is not in line with previous research that found that competence significantly affects job satisfaction (Jusmin et al., 2016). This problem can be seen in the role of employees in completing work and reporting. Not all employees have skills in using information technology such as computers and digital applications, so that the task becomes a workload for several employees with good competence.

Then this study supports the fifth hypothesis where there is a significant influence of organizational culture on employee performance. This result is seen from the path coefficient value of 0.277 and $\mathrm{p}$-value of $0.048<0.05$, which means a significant effect. These results support research of Makawi et al. (2020), and Maryati et al. (2019). The observed local organization (Yapen Islands Regency's DPMPTSP) has a supportive organizational culture. Leaders assist employees in solving problems they face, and employees are given the freedom to express their opinions to solve problems.

The subsequent hypothesis testing proves that organizational culture significantly influences job satisfaction and proves the sixth hypothesis. This finding is indicated by the path coefficient value of 0.354 and the p-value of $0.024<0.05$, which means a significant effect. This finding supports previous research that also found that organizational culture significantly affects job satisfaction (Al-Sada et al., 2017). Thus, a supportive, participatory culture characterizes the organizational culture in the observed local organization. Furthermore, the observed respondents explicitly reveal their satisfaction with the organization's democratic communication patterns. 
Then this study proves the seventh hypothesis where job satisfaction is proven to significantly affect employee performance seen from the path coefficient value of 0.430 and pvalue of $0.006<0.05$. These results support previous research that also found that job satisfaction significantly affects employee performance (Jusmin et al., 2016; Kawiana et al., 2018). Employees at Yapen Islands Regency's DPMPTSP are satisfied with a safe and comfortable workplace, get learning opportunities and responsibilities from the leadership, and have solid colleagues. When employees are satisfied with these things, employees are more enthusiastic in working and spur them to give the best performance.

Furthermore, testing the mediation hypothesis (Table 6) shows that only one hypothesis is proven, namely the eighth hypothesis. Job satisfaction is proven to fully mediate the relationship of leadership to employee performance which supports the results of previous research (Makawi et al., 2020; Pudyaningsih et al., 2020). Leadership does not directly affect employee performance but indirectly affects employee performance through job satisfaction. Employees are satisfied with supportive and respectful leadership and a safe and comfortable workplace so that job satisfaction can mediate the relationship between leadership and employee performance.

Table 6. Mediation Test Results

\begin{tabular}{|c|c|c|c|c|c|}
\hline $\begin{array}{l}\text { Hyp } \\
\text { othe } \\
\text { sis }\end{array}$ & Model & $\begin{array}{c}\text { Path } \\
\text { Coefficien } \\
t \\
\end{array}$ & $\begin{array}{c}\text { P-Values } \\
\text { Direct } \\
\text { Effect }\end{array}$ & $\begin{array}{c}\text { P-Values } \\
\text { Indirect } \\
\text { Effect }\end{array}$ & Information \\
\hline H8 & (a) X1 $\rightarrow$ Z & 0.453 & $0.001^{* *}$ & \multirow{3}{*}{$0.034^{*}$} & \multirow{3}{*}{$\begin{array}{l}\mathrm{a}, \mathrm{b} \text { is significant } \\
\text { while } \mathrm{c} \text { is not } \\
\text { significant }= \\
\text { fully mediation }\end{array}$} \\
\hline & (b) $\mathrm{Z} \rightarrow \mathrm{Y}$ & 0.430 & $0.006^{* *}$ & & \\
\hline & (c) $\mathrm{X} 1 \rightarrow \mathrm{Y}$ & 0.094 & 0.600 & & \\
\hline \multirow[t]{3}{*}{ H9 } & (a) $\mathrm{X} 2 \rightarrow \mathrm{Z}$ & 0.076 & 0.547 & & \multirow{3}{*}{$\begin{array}{l}a \text { is not } \\
\text { significant }=\text { no } \\
\text { mediation }\end{array}$} \\
\hline & (b) $\mathrm{Z} \rightarrow \mathrm{Y}$ & 0.430 & $0.006^{* *}$ & 0.584 & \\
\hline & (c) $\mathrm{X} 2 \rightarrow \mathrm{Y}$ & 0.254 & $0.045^{*}$ & & \\
\hline \multirow[t]{3}{*}{$\mathrm{H} 10$} & (a) X3 $\rightarrow Z$ & 0.354 & $0.024 *$ & \multirow{3}{*}{0.088} & \multirow{3}{*}{$\begin{array}{l}\mathrm{a}, \mathrm{b} \text {, and } \mathrm{c} \text { are } \\
\text { significant, but } \\
\text { the } \mathrm{p} \text {-value } \\
\text { indirect effect is } \\
\text { not significant }= \\
\text { no mediation }\end{array}$} \\
\hline & (b) $\mathrm{Z} \rightarrow \mathrm{Y}$ & 0.430 & $0.006^{* *}$ & & \\
\hline & (c) $\mathrm{X} 3 \rightarrow \mathrm{Y}$ & 0.277 & $0.048^{*}$ & & \\
\hline
\end{tabular}

Hypotheses nine and ten are not proven because the analysis results show that job satisfaction cannot mediate the relationship between competence and organizational culture on employee performance. This finding is not in line with previous researchers (Jusmin et al., 2016; Makawi et al., 2020). In carrying out employee performance activities, it is still found that all employees do not understand the clarity of suggestions and expectations for the achievements to be achieved by the organization. Therefore, although employees feel satisfied with their work, some employees are still negligent and tend to ignore work-related responsibilities, lack of curiosity, and employee creativity in completing work not to improve their performance. 


\section{Conclusion}

Based on the research objectives, research hypotheses, discussion, and data analysis, it can be concluded that 1) leadership has no significant effect on employee performance but has a significant effect on job satisfaction; 2) competence has a significant effect on employee performance, but is not significant in influencing job satisfaction; 3) organizational culture has a significant effect on employee performance and job satisfaction; 4) job satisfaction has a significant effect on employee performance; 5) job satisfaction can mediate the relationship of leadership to employee performance, but cannot mediate the relationship of competence and organizational culture to employee performance.

In this study, researchers still found limitations in the research process, so it expects future researchers to improve them. The limitations in this study are 1) the variables studied in this study are still few, so the results of the study are not comprehensive; 2) the results of this study are only supported by interviews with one resource person so that the assessment may tend to be subjective; 3) this study only uses a small number of samples so that the results of the study cannot be generalized to a broader population.

Based on the study results and the study's limitations, the researchers provide suggestions or managerial implications for leaders in Yapen Islands Regency's DPMPTSP. Regarding the leadership variable, the leaders in the observed local organization should be able to convey the goals that employees can achieve. Leaders can also discuss goals with employees, ask if employees understand these goals, and ask employees for opinions. In addition, leaders must be fairer and support goals because employees expect leaders to be fair in giving reprimands and sanctions for the undisciplined behavior.

Regarding competency variables, leaders can improve the abilities and skills of employees by prioritizing programs and activities in the form of education and training for personnel as well as computerization training and internet network access. Regarding organizational culture variables, the leadership at Yapen Islands Regency's DPMPTSP needs to provide more opportunities or authority to employees to create new ideas and ways of working in completing work. Regarding job satisfaction variables, the leaders of the observed local organization can review the number of salaries, bonuses, or allowances that employees receive whether they can meet the needs and are following the performance that the employees provide.

For further researchers, it expects to conduct research using other variables to determine their influence on improving the employees' performance. In addition, it can use a larger sample so that the research results can be generalized to a broader population. Finally, interviews with research samples are also needed to support more accurate research results.

\section{References}

Al-Sada, M., Al-Esmael, B., \& Faisal, M. N. (2017). Influence of organizational culture and leadership style on employee satisfaction, commitment and motivation in the educational sector in Qatar. EuroMed Journal of Business, 12(2), 163-188. https://doi.org/10.1108/EMJB-02-2016-0003

Bernardin, H. J., \& Russel, J. E. A. (2013). Human Resource Management. New York: McGraw Hill.

Braun, S., Peus, C., Weisweiler, S., \& Frey, D. (2013). Transformational leadership, job satisfaction, and team performance: A multilevel mediation model of trust. The 
$\begin{array}{lcc}\text { Leadership } & \text { Quarterly, } & \text { 24(1), } \\ \text { https://doi.org/https://doi.org/10.1016/j.leaqua.2012.11.006 }\end{array}$

$270-283$.

Chin, W. W. (2010). How to Write Up and Report PLS Analyses BT - Handbook of Partial Least Squares: Concepts, Methods and Applications. In V. Esposito Vinzi, W. W. Chin, J. Henseler, \& H. Wang (Ed.), Handbook of Partial Least Square (hal. 655-690). Springer Berlin Heidelberg. https://doi.org/10.1007/978-3-540-32827-8_29

Chin, W. W., Peterson, R. A., \& Brown, S. P. (2008). Structural Equation Modeling in Marketing: Some Practical Reminders. Journal of Marketing Theory and Practice, 16(4), 287-298. https://doi.org/10.2753/MTP1069-6679160402

Fitri, R., Marnis, M., \& Garnasih, R. L. (2020). Pengaruh Kompetensi dan Diklat terhadap Kepuasan Kerja dan Kinerja Pegawai Dinas Penanaman Modal dan Pelayanan Terpadu Satu Pintu Provinsi Riau. Procuratio: Jurnal Ilmiah Manajemen, 8(3), 291307.

Fried, Y., Shirom, A., Gilboa, S., \& Cooper, C. L. (2008). The mediating effects of job satisfaction and propensity to leave on role stress-job performance relationships: Combining meta-analysis and structural equation modeling. International Journal of Stress Management, 15(4), 305.

Galup, S. D., Klein, G., \& Jiang, J. J. (2008). The Impacts of Job Characteristics on is Employee Satisfaction: A Comparison between Permanent and Temporary Employees. Journal of Computer Information Systems, 48(4), 58-68. https://doi.org/10.1080/08874417.2008.11646035

Hair, J. F., Hult, G. T. M., Ringle, C., \& Sarstedt, M. (2016). A Primer on Partial Least Squares Structural Equation Modeling (PLS-SEM) (2 ed.). Los Angeles: Sage.

Johnson, S. D., \& Bechler, C. (1998). Examining the relationship between listening effectiveness and leadership emergence perceptions, behaviors, and recall. Small Group Research, 29, 452-471. https://doi.org/10.1177/1046496498294003

Jusmin, A., Said, S., Bima, M. J., \& Alam, R. (2016). Specific determinants of work motivation, competence, organizational climate, job satisfaction and individual performance: A study among lecturers. Journal of Business and Management Sciences, 4(3), 53-59. https://doi.org/10.12691/jbms-4-3-1

Kaiser, R. B., Hogan, R., \& Craig, S. B. (2008). Leadership and the fate of organizations. In American Psychologist (Vol. 63, Nomor 2, hal. 96-110). American Psychological Association. https://doi.org/10.1037/0003-066X.63.2.96

Kawiana, I. P., Dewi, L. K. C., Martini, L., \& Suardana, I. (2018). The influence of organizational culture, employee satisfaction, personality, and organizational commitment towards employee performance. International Research Journal of Management, IT and Social Sciences, 5(3), 35-45. https://doi.org/10.21744/IRJMIS.V5I3.666

Khaeriah, K., Razak, M., \& Alam, S. (2020). Pengaruh Kompetensi, Kesadaran. Pelatihan, Infrastruktur dan Lingkungan Kerja terhadap Kinerja Pegawai Pada Dinas Penanaman Modal, Pelayanan Terpadu Satu Pintu dan Tenaga Kerja. Nobel Management Review, 1(1), 1-8.

Kojo, O., Tinangon, J. J., \& Afandi, D. (2019). Analisis Penilaian Kinerja Sektor Publik (Studi Kasus Pada Dinas Penanaman Modal dan Pelayanan Terpadu Satu Pintu Kabupaten Minahasa Tenggara). Jurnal EMBA: Jurnal Riset Ekonomi, Manajemen, Bisnis dan Akuntansi, 7(3), 4281-4290.

Lobdell, C. L., Sonoda, K. T., \& Arnold, W. E. (1993). The Influence of Perceived Supervisor Listening Behavior on Employee Commitment. International Listening Association. Journal, 7(1), 92-110. https://doi.org/10.1080/10904018.1993.10499116

Makawi, A. A., Pahlawan, B. R., Andika, D., \& Prasetyaningtyas, S. W. (2020). Job Satisfaction as Mediator: The Role of Leadership Style and Organizational Culture on Employee 
Performance in Budget-Hotel. Journal of Research in Business, Economics, and Education, 2(6), 1427-1441.

Maryati, T., Astuti, R. J., \& Udin, U. (2019). The effect of spiritual leadership and organizational culture on employee performance: The mediating role of job satisfaction. International Journal of Innovation, Creativity and Change, 9(3), 130-143.

Mazurchenko, A., \& Maršíková, K. (2019). Digitally-Powered Human Resource Management: Skills and Roles in the Digital Era. Acta Informatica Pragensia, 8(2), 72-87.

Pudyaningsih, A., Dwiharto, J., \& Ghifary, M. (2020). The role of work satisfaction as a mediation leadership on employee performance. Management Science Letters, 10(16), 3735-3740. https://doi.org/10.5267/j.msl.2020.7.039

Rahmat, M. A., Brasit, N., \& Kadir, N. (2020). The Influence of Leadership Style and Work Discipline on Service Quality and Employee Performance in The Investment Office and One Stop Integrated Service in Makassar City. Hasanuddin Journal of Applied Business and Entrepreneurship, 3(4), 58-71.

Salman, M., Ganie, S. A., \& Saleem, I. (2020). Employee Competencies as Predictors of Organizational Performance: A Study of Public and Private Sector Banks. Management and Labour Studies, 45(4), 416-432. https://doi.org/10.1177/0258042X20939014

Schein, E. H. (2004). Organizational Culture and Leadership. San Francisco, CA: Jossey-Bass.

Shahab, M. A., \& Nisa, I. (2014). The influence of leadership and work attitudes toward job satisfaction and performance of employee. International Journal of Managerial Studies and Research, 2(5), 69-77.

Spencer, L. M., \& Spencer, S. M. (1993). Competence at work: Models for a superior performance. Wiley.

Subriah, S., Razak, M., \& Alam, S. (2020). Pengaruh Motivasi Kerja, Kepemimpinan dan Disiplin Kerja terhadap Kinerja Pegawai Dinas Penanaman Modal dan Pelayanan Teradu Satu Pintu Kabupaten Majene. Nobel Management Review, 1(1), 38-49.

Sugiyono. (2013). Metode Penelitian Kuantitatif, Kualitatif dan R\&D. Bandung: Alfabeta CV.

Sulantara, I. M., Mareni, P. K., Sapta, I. K. S., \& Suryani, N. K. (2020). The Effect of Leadership Style and Competence on Employee Performance. European Journal of Business and Management Research, 5(5), 1-8. https://doi.org/10.24018/ejbmr.2020.5.5.494

Warokka, A. (2010). Estructura de propiedad y gobierno corporativo en las empresas asiáticas tras la crisis financiera de 1997. Revista de Responsibilidad Social de la Empresa 2(2), 141-179.

Wiadnyana, D. G. A., Gama, G., \& Rismawan, P. A. E. (2021). Pengaruh Kecerdasan Emosional, Kedisiplinan dan Kompensasi terhadap Kinerja Pegawai Dinas Penanaman Modal dan Pelayanan Terpadu Satu Pintu Kabupaten Gianyar. EMAS, 2(2), 1-15.

Yulianto, E., \& Ali, H. (2017). Nilai Budaya Organisasi pada Dinas Penanaman Modal dan Pelayanan Terpadu Satu Pintu Provinsi DKI Jakarta dan Pengaruhnya terhadap Kepuasan Pelayanan Publik di Provinsi DKI Jakarta. Jakarta: Universitas Mercu Buana. 